\title{
Intravenously Injected Insulin-like Growth Factor (IGF) I/IGF Binding Protein-3 Complex Exerts Insulin-like Effects in Hypophysectomized, but Not in Normal Rats
}

\author{
Jürgen Zapf, Christina Hauri, Eva Futo, Mehboob Hussain, Jonas Rutishauser, Christopher A. Maack, * \\ and E. Rudolf Froesch \\ Metabolic Unit, Department of Medicine, University Hospital, CH-8091 Zürich, Switzerland; and *Celtrix Pharmaceuticals, Inc., \\ Santa Clara, California 95054
}

\begin{abstract}
Insulin-like growth factor (IGF) circulates in blood in two large molecular mass forms of 150 and $40 \mathrm{kD}$. Under normal conditions, most of the IGF is bound to the 150-kD complex by which it is retained in the circulation and therefore unable to exert acute insulin-like actions. The aim of this study was to answer the question whether or not IGF in the 40$\mathrm{kD}$ complex is bioavailable to insulin target tissues and thus can cause acute insulin-like effects in vivo. Intravenously injected 1:1 molar recombinant human (rh) IGF I/rhIGF binding protein (BP)-3 complex lowered blood glucose and stimulated glycogen synthesis in diaphragm of hypophysectomized, but not of normal rats. The serum half-lives of the two components of the complex were similar to each other, but considerably shorter in hypox than in normal rats. On neutral gel filtration of serum both components of the injected complex appeared predominantly in the $150-\mathrm{kD}$ region in normal rats. In hypox rats which lack the 150-kD complex they were found in the 40-kD region and disappeared rapidly from the circulation. We conclude that in the absence of the 150-kD complex, IGF associated with the 40-kD complex can rapidly leave the vascular compartment, reach insulin or type 1 IGF receptors and exert acute insulin-like effects. (J. Clin. Invest. 1995. 95:179-186.) Key words: $\mathrm{U}-{ }^{14} \mathrm{C}$-glucose $\bullet$ blood sugar $\bullet$ glycogen synthesis • 150- and 40-kD IGFBP complexes - IGFBP-3 and IGF I half-lives
\end{abstract}

\section{Introduction}

Insulin-like growth factor I circulates in blood in two large molecular mass forms (1). Most of the IGF I is associated with a $150-\mathrm{kD}$ complex $(1,2)$ consisting of a glycosylated acidlabile protein (ALS, ${ }^{1} \alpha$ subunit), glycosylated IGF binding protein-3 (IGFBP-3, $\beta$ subunit) and IGF I itself ( $\gamma$ subunit)

Address correspondence to Jürgen Zapf, Metabolic Unit, Dept. of Internal Medicine, University Hospital, CH-8091 Zürich. Phone: 1-255-3585; FAX: 1-255-44-47.

Received for publication 28 July 1994.

1. Abbreviations used in this paper: ALS, acid-labile subunit; hypox, hypophysectomized; IGFBP, insulin-like growth factor binding protein; rh, recombinant human.

J. Clin. Invest.

(C) The American Society for Clinical Investigation, Inc. 0021-9738/95/01/0179/08 $\$ 2.00$

Volume 95, January 1995, 179-186
(3). A smaller portion of IGF I is found in a $40-\mathrm{kD}$ a complex $(1,2,4)$ which contains IGFBP-2, $-3,-4(5,6)$ and $-6(7)$, besides small amounts of IGFBP-1. In normal human and rat serum, free IGF I is barely detectable $(8,9)$. In the $150-\mathrm{kD}$ complex, IGF I has a long serum half-life $(8,10)$ and restricted bioavailability to tissue receptors and therefore does not participate in the regulation of glucose homeostasis (1). However, when injected intravenously, IGF I induces hypoglycemia (10, $11,12)$ and stimulates glycogen synthesis in skeletal and heart muscle $(10,12)$ and lipid synthesis in adipose tissue (10). These effects are mainly due to a transient increase of free IGF I because the binding capacity of circulating IGFBPs is temporarily overridden $(10,11)$.

One of the still unanswered questions is whether or not IGF associated with the $40-\mathrm{kD}$ complex can exert acute insulin-like effects as does free IGF. To this end it would have to leave the circulation and interact with insulin and/or type 1 IGF receptors. The following findings indicate that this may be the case: (a) In contrast to the $150-\mathrm{kD}$ complex, the $40-\mathrm{kD}$ complex is found in interstitial fluid suggesting that it passes through capillaries (13). IGF levels in interstitial fluid are lower than in serum $(13,14)$. This would be expected if only the $40-\mathrm{kD}-$ associated, but not the $150-\mathrm{kD}$-bound IGF I passed into the interstitial space. (b) In humans, the serum half-life of IGF I (and II) in the $40-\mathrm{kD}$ complex is only $20-30 \mathrm{~min}$, as compared with $12-14 \mathrm{~h}$ in the $150-\mathrm{kD}$ complex (8), pointing to a high turnover of the former. $(c)$ In extrapancreatic tumor hypoglycemia most of the circulating big IGF II produced by the tumor and held responsible for hypoglycemia is bound to the $40-\mathrm{kD}$ complex $(5,15,16)$. The availability of recombinant human (rh) IGFBP-3 offered the possibility to address the above issue more directly. We have injected 1:1 molar IGF I/IGFBP-3 complex, IGFBP-3 alone or IGF I alone intravenously into normal or hypophysectomized (hypox) rats and measured effects on blood glucose, glycogen synthesis in diaphragm and lipid synthesis in adipose tissue. At the same time, the serum half-lives of IGF I and IGFBP-3 after injection of the complex were determined. The results show that the 1:1 molar IGF I/IGFBP3 complex lowers blood glucose and stimulates glycogen synthesis in diaphragm of hypox but not of normal animals. The serum half-lives of each component of the IGF I/IGFBP-3 complex are similar, but they are considerably shorter in hypox than in normal rats.

\section{Methods}

Animals and experimental procedure

Normal and hypox male Tif Rai rats (140-170 g) were used for the study. Hypophysectomy was carried out between 5 and $6 \mathrm{wk}$ after birth (courtesy of Dr. K. Müller and M. Cortesi, Ciba-Geigy, Basel, 
Switzerland). Animals had free access to food and drinking water and were kept on a 12-h light/dark cycle. Experiments were performed 2 wk after hypophysectomy in animals which had not gained $>2-3 \mathrm{~g} /$ wk. Before the experiment, the animals received $0.25 \mathrm{ml}$ (hypox rats) or $0.35 \mathrm{ml}$ (normal rats) Valium/100 g body weight sc. $15-20 \mathrm{~min}$ later, $1 \mathrm{ml}$ of phosphate-buffered saline (PBS) $/ 0.1 \%$ human serum albumin (HSA) containing $1 \mu \mathrm{Ci}$ of $\mathrm{U}-{ }^{14} \mathrm{C}$-glucose (see below) and one of the following additions, was injected into a tail vein: $(a)$ none (vehicle alone), ( $b$ ) $132 \mu \mathrm{g}$ of rhIGF I alone (Ciba-Geigy AG, Basel), (c) $500 \mu \mathrm{g}$ of rhIGFBP-3 alone (nonglycosylated, Celtrix, Santa Clara, CA), d) a 1:1 molar complex of the two compounds. Animals were anaesthetized with $0.2 \mathrm{ml} / \mathrm{kg}$ body weight of Innovar Vet (Pitman Moore, Washington Crossing, $\mathrm{NJ}$ ) and bled by aortic puncture at 5, 20, 60,120 , and $240 \mathrm{~min}$. For each time point three animals each were injected. To save hypox animals, only one time point at $20 \mathrm{~min}$ was chosen in the vehicle-treated group. Blood was kept on ice for $30 \mathrm{~min}$ and centrifuged for $15 \mathrm{~min}$ at $1,000 \mathrm{~g}$ and $4^{\circ} \mathrm{C} .25 \mu \mathrm{l}$ of the serum was counted immediately for ${ }^{14} \mathrm{C}$-radioactivity in $10 \mathrm{ml}$ of Instagel (Packard, Downers Grove, IL) in a $\beta$ counter (Beckman, Irvine, CA). Glucose was determined by a glucose analyzer (Beckman, Fullerton, CA). The rest of the serum was stored at $-20^{\circ} \mathrm{C}$ until used for analysis. $\mathrm{U}-{ }^{14} \mathrm{C}$ glucose incorporation into diaphragm glycogen and into total lipids of epididymal fat pad was determined and calculated as described in detail earlier (10).

IGF I/IGFBP-3 complex formation was achieved by incubating 8.6 $\mathrm{mg}$ of rhIGFBP-3 with $2.28 \mathrm{mg}$ of rhIGF I in $2.2 \mathrm{ml}$ of PBS/ $10 \mathrm{mM}$ sodium acetate, $\mathrm{pH} 6.0$ (because rhIGFBP-3 is better soluble below $\mathrm{pH}$ 7.0 ), at $4^{\circ} \mathrm{C}$ over night. Before the experiment, the mixture was diluted into $15 \mathrm{ml}$ of PBS/0.1\% HSA pH 7.2, and D-U- ${ }^{14} \mathrm{C}$-glucose (specific radioactivity $>230 \mathrm{mCi} / \mathrm{mmol}$, Amersham, UK) was added to give a final radioactivity of $1 \mu \mathrm{Ci} / \mathrm{ml}$. Under the above conditions, the concentration of free rhIGF I in the final solution as measured by neutral sizing chromatography (16) and by immunometric assay (17) was $<5 \%$ of the total rhIGF I.

\section{Analysis of sera}

Determination of immunoreactive IGF I. $0.15 \mathrm{ml}$ of $\mathrm{PBS} / 0.2 \%$ (wt/ vol) HSA, pH 7.4, was added to $0.1 \mathrm{ml}$ of serum and the mixture was acid-treated and run on SepPak $\mathrm{C}_{18}$-cartridges (Waters, Milford, MS) according to the protocol supplied by Immunonuclear (Stillwater, MN). After reconstitution with $1 \mathrm{ml}$ of $\mathrm{PBS} / 0.2 \% \mathrm{HSA}$, all samples were assayed at three different dilutions by RIA using human rhIGF I as a standard $(4,19)$. The three dilutions gave comparable values from which the mean value was calculated. Rat IGF I does not cross react in this assay. Determination of endogenous rat IGF I in saline- or IGFBP-3-treated rats was performed with another IGF I-antiserum (gift from the late Dr. K. Reber, Hoffmann La Roche, Basel, Switzerland) (4) which cross reacts with rat IGF I, and with purified rat IGF I (kindly provided by Dr. M. Kobayashi, Fujisawa, Osaka, Japan) as a standard.

Determination of IGFBP-3. This was performed by two different methods: by IGFBP-3 RIA and by Western ligand blotting.

The RIA was carried out in a total volume of $0.4 \mathrm{ml}$ of $30 \mathrm{mM}$ sodium phosphate buffer $/ 0.25 \%$ (wt/vol) BSA containing $180 \mathrm{mM}$ $\mathrm{NaCl}, 0.1 \%$ (wt/vol) Tween 20 , between 0.31 and $20 \mathrm{ng}$ of nonglycosylated IGFBP-3 (standard curve) or between 0.05 and $2 \mu \mathrm{l}$ of rat serum, $30,000 \mathrm{cpm}$ of ${ }^{125}$ I-labeled glycosylated IGFBP-3 (specific activity $\sim 160 \mu \mathrm{Ci} / \mu \mathrm{g}$, Anawa, Wangen, Switzerland) and $0.1 \mathrm{ml}$ of 1:1,500 diluted rabbit anti-human IGFBP-3 antiserum (Celtrix, Santa Clara, CA). This antiserum does not crossreact with rat IGFBP-3, but binds glycosylated and nonglycosylated rhIGFBP-3 as well as intact and truncated IGFBP-3 purified from human serum. After $24 \mathrm{~h}$ at $4^{\circ} \mathrm{C}, 100 \mu \mathrm{l}$ of 1:10 diluted goat anti-rabbit $\gamma$-globulin antiserum (Calbiochem Corp., La Jolla, CA) and $100 \mu \mathrm{l}(20 \mu \mathrm{g})$ of rabbit $\gamma$-globulin (ICN Biomedicals, Costa Mesa, CA) was added and the mixture was incubated for $45 \mathrm{~min}$ at $4^{\circ} \mathrm{C}$. Finally, $1 \mathrm{ml}$ of $6.4 \%(\mathrm{wt} / \mathrm{vol})$, polyethylene glycol (6000; Merck-Schuchardt, Hohenbrunn, Germany) dissolved in $30 \mathrm{mM}$ sodium phosphate buffer, $\mathrm{pH} 7.2$, was added and the mixture centrifuged for $30 \mathrm{~min}$ at $4^{\circ} \mathrm{C}$ and $3,000 \mathrm{rpm}$. The supernate was de- canted and the pellet counted in a $\gamma$ counter. All serum samples were measured at three different dilutions. They gave comparable values from which the mean value was calculated. Inter- and intra-assay variations were $4.4(n=7)$ and $1.7 \%(n=15)$, respectively. Total binding of ${ }^{125}$ I-rhIGFBP-3 was $21 \pm 3 \%(n=4$, mean \pm SD $)$ and nonspecific binding $3.8 \pm 1.4 \%(n=4$, mean \pm SD $)$. The recovery of rhIGFBP-3 added to rat serum was $96 \pm 5.4 \%(n=5$, mean $\pm \mathrm{SD})$. Half-maximal displacement of ${ }^{125} \mathrm{I}$-rhIGFBP- 3 was achieved at $5.2 \pm 0.6 \mathrm{ng} / \mathrm{ml}$ of unlabeled rhIGFBP$3(n=4$, mean $\pm \mathrm{SD})$, and the lowest concentration of rhIGFBP-3 detectable with this assay was $1.5 \mathrm{ng} / \mathrm{ml}(0.6 \mathrm{ng} /$ tube $)$.

Determination of injected rhIGFBP- 3 by Western ligand blotting was performed after electrophoresis of $2 \mu \mathrm{l}$ of serum on SDS/15\% polyacrylamide gels and electroblotting on nitrocellulose $(4,20)$. After exposure of the washed and air-dried membranes to an X-ray film ( Kodak X-Omat AR; Eastman Kodak Co., Rochester, NY) the membranes were fitted on the autoradiogram on a fluorescent screen and the bands between 32 and $34 \mathrm{kD}$ representing nonglycosylated human IGFBP-3 were cut-out and counted in a $\gamma$-counter (5). Corresponding strips obtained from control sera of saline-treated normal and hypox rats were used to subtract "background activity" and correct for binding of tracer to endogenous rat IGFBPs in the $32-34-\mathrm{kD}$ region. Results are expressed as cpm/band.

Sephadex gel-filtration experiments. $0.6 \mathrm{ml}$ of pooled serum from three rats per time interval $(5,20,60 \mathrm{~min})$ was gel-filtered on a Sephadex G-200 column $(2 \times 70 \mathrm{~cm})$ and eluted with Dulbecco's PBS $(\mathrm{pH} 7.4$, containing $0.02 \%$ of $\mathrm{NaN}_{3}$, pumping rate $10 \mathrm{ml} / \mathrm{h}$ ). The column had previously been calibrated with various molecular mass markers and with normal and hypox rat serum preequilibrated with $3-4 \times 10^{5} \mathrm{cpm}$ ${ }^{125} \mathrm{I}$-IGF II, ( specific radioactivity $300-400 \mu \mathrm{Ci} / \mu \mathrm{g}$; Anawa, Wangen, Switzerland) to localize the 150 - and $40-\mathrm{kD}$ IGFBP complexes (4). The $40-\mathrm{kD}{ }^{125}$ I-IGF II complexes of both normal and hypox rat serum eluted within the same molecular mass range $(25-100 \mathrm{kD}$; see also ref. 4 ). The $150-\mathrm{kD}$ complex is lacking in hypox rat serum (4), and the radioactivity eluting within this range $(100-270 \mathrm{kD})$ was $<10 \%$ of the $40-\mathrm{kD}$ peak. Eluted fractions $(2.4 \mathrm{ml})$ were pooled according to the location of the two complexes (pooled fractions 50-55 and 56-61 representing the $150-\mathrm{kD}$ complex, and pooled fractions $62-67,68-73$, $74-79$, and $80-85$ representing the $40-\mathrm{kD}$ complex). The six pools were dialyzed against $0.1 \mathrm{M} \mathrm{NH}_{4} \mathrm{HCO}_{3}$ in Spectrapor tubing (Spectrum Medical Industries, Houston, TX; molecular weight cut-off 3,500), lyophilized, dissolved in $1.0 \mathrm{ml}$ of $\mathrm{H}_{2} \mathrm{O}$ and rhIGFBP-3 was measured at 3 different dilutions in the IGFBP-3 RIA (see above). For determination of irIGF I, 0.1-ml aliquots of each pool were diluted with $0.15 \mathrm{ml}$ $\mathrm{PBS} / 0.2 \% \mathrm{HSA}, \mathrm{pH} 7.4$, and processed over SepPak $\mathrm{C}_{18}$-cartridges as described above for serum.

Statistics. Statistical analysis was performed using the unpaired Student's $t$ test.

\section{Results}

Effects of IGF I, IGFBP-3, and IGF I/IGFBP-3 complex on serum glucose, serum ${ }^{14} \mathrm{C}$-radioactivity, and specific glucose radioactivity in normal and hypox rats. Neither i.v.-injected IGFBP-3 nor IGF I/IGFBP-3 complex caused significant changes of the serum glucose levels in normal rats (Fig. $1 A$ ). This was true whether values of the same curve were compared to each other or whether corresponding values of the two curves were compared to each other or to those of saline-treated animals. Only the IGF I bolus lowered blood glucose significantly after 20 min (Fig. 1 $A$ ). Like in normal animals, IGFBP-3 alone did not cause significant changes of the blood sugar level in hypox rats although there appeared to be a tendency towards lower glucose levels at $20 \mathrm{~min}$, as also observed in normal animals. However, this value was neither statistically different from the $5 \mathrm{~min}$ value nor from the corresponding $20 \mathrm{~min}$ value of saline-treated animals. In contrast to normal animals, the 

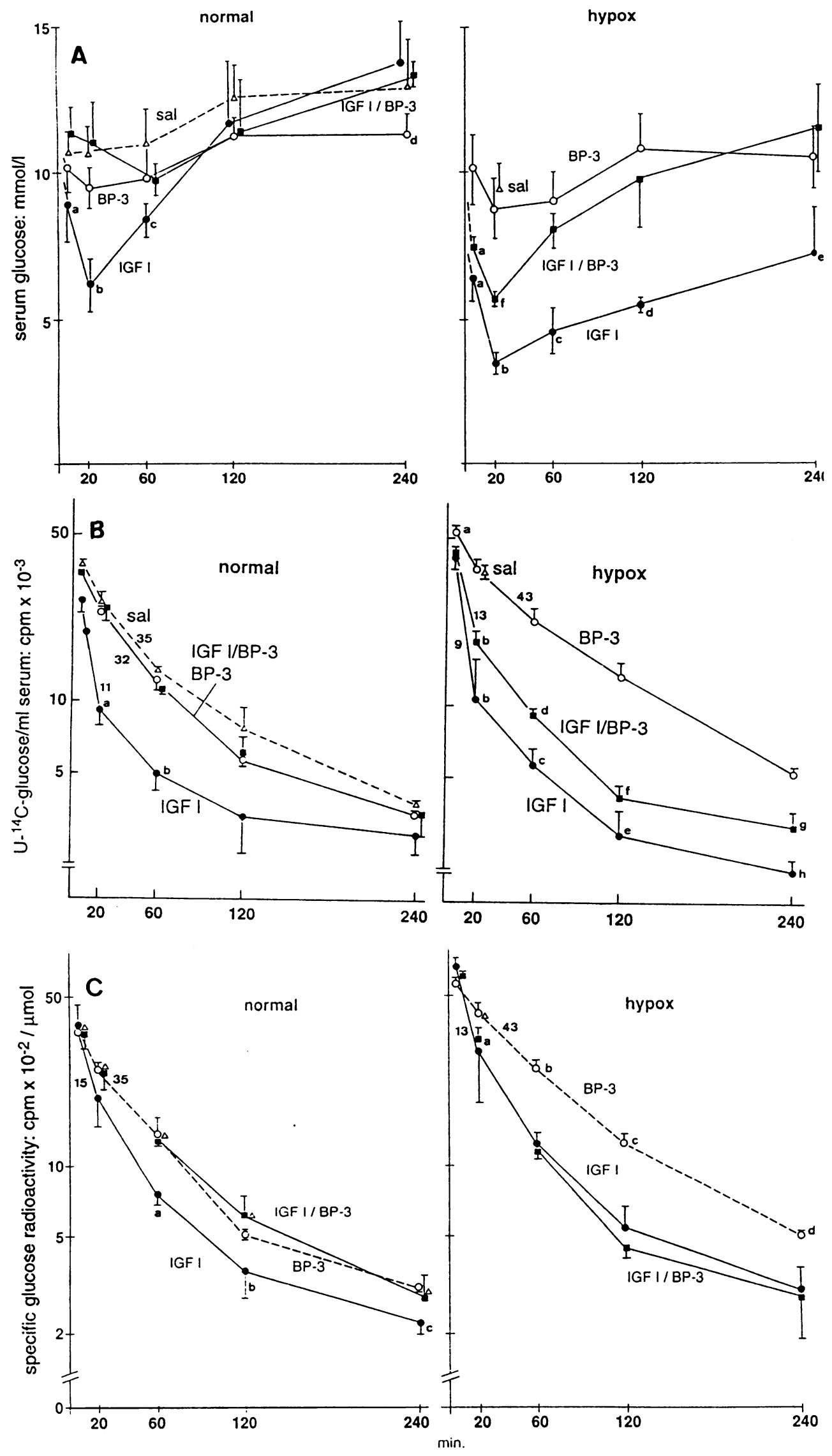

Figure 1. Effect of i.v. injected rhIGF I (132 $\mu \mathrm{g}, \bullet)$, rhIGFBP-3 $(500 \mu \mathrm{g}, \mathrm{O})$, or of 1:1 molar rhIGF I/rhIGFBP-3 complex ( $\square$ ) on serum glucose levels $(A)$, and serum disappearance rates of ${ }^{14} \mathrm{C}$ radioactivity $(B)$, and specific glucose radioactivity $(C)$ in normal and hypox rats. $1 \mu \mathrm{Ci}$ of $\mathrm{U}-\left[{ }^{14} \mathrm{C}\right]$ glucose was injected together with each of the three compounds. All values are the mean $\pm S D$ of three animals per time point in each treatment group. In the saline (sal, $\Delta$ )- and IGFBP3 -treated normal groups, six animals each were injected for the time points 5,20 , and $60 \mathrm{~min}$. Half-lives of ${ }^{14} \mathrm{C}$-radioactivity and specific glucose radioactivity were determined on the curves starting $5 \mathrm{~min}$ after injection. Statistics: $(A$, left panel) $a, P<0.05$ vs sal; $b, P$ $<0.0005$ vs $\mathrm{BP}-3$ and sal and $<0.01$ vs IGF I/BP-3; $c, P<0.02$ vs sal and $<0.05$ vs IGF I/BP-3; $d, P<0.02$ vs IGF I/BP-3 and $<0.05$ vs sal. ( $A$, right panel) $a, P$ $<0.02$ vs BP-3; $b, P>0.001$ vs BP-3 and IGF I/BP-3; $c, P<0.05$ vs BP-3 and IGF I/BP-3; $d, P$ $<0.002$ vs $\mathrm{BP}-3$ and $<0.02$ vs IGF I/BP-3; $e, P<0.05$ vs IGF I/BP3. (B, left panel) $a, P<0.0001$ vs sal and BP-3 and $<0.002$ vs IGF I/BP- $3 ; b, P<0.001$ vs sal and IGF I/BP-3 and $<0.0005$ vs BP-3. ( $B$, right panel) $a, P<0.05$ vs IGF I/BP-3; $b, P<0.002$ vs BP-3 and sal; $c, P<0.001 \mathrm{vs} \mathrm{BP-3}$ and $<0.01$ vs IGF I/BP- $3 ; d, P$ $<0.002$ vs $\mathrm{BP}-3$; $e, P<0.001$ vs BP- $3 ; f, P<0.0005$ vs BP- $3 ; g, P$ $<0.01$ vs $\mathrm{BP}-3 ; \boldsymbol{h}, P<0.0005$ vs BP-3 and $<0.05$ vs IGF I/BP-3. ( $C$, left panel) $a, P<0.001$ vs BP3 and IGF I/BP-3 and $<0.005$ vs sal; $b, P<0.05$ vs sal and BP-3; c, $P<0.02$ vs BP-3. (C, right panel) $a, P<0.02$ vs BP-3; $b, P$ $<0.001$ vs IGF I and IGF I/BP-3; $c, P<0.005$ vs IGF I and iGF I/BP-3; $d, P<0.02$ vs IGF I and IGF I/BP-3. Numbers in the graphs denote half-lives determined after the time point $5 \mathrm{~min}$. 
IGF I/IGFBP-3 complex significantly lowered serum glucose in hypox animals after 5 and $20 \mathrm{~min}$, as compared to IGFBP3 alone. However, the hypoglycemic effect was more pronounced in the case of the IGF I bolus and lasted for $4 \mathrm{~h}$.

The disappearance rates of serum $\left[{ }^{14} \mathrm{C}\right]$ glucose and of specific glucose radioactivity (Fig. $1, B$ and $C$ ) from the sera reflect the changes in serum glucose: $5 \mathrm{~min}$ after injection, $\left[{ }^{14} \mathrm{C}\right]-$ glucose radioactivity in normal rats decreased significantly faster after the IGF I bolus (half-life $\sim 11 \mathrm{~min}$ ) than after IGFBP-3 or the IGF I/IGFBP-3 complex (half-lives $\sim 32 \mathrm{~min}$ ). In hypox animals, however, not only IGF I but also the IGF I/ IGFBP-3 complex caused an enhanced decrease of the serum $\left[{ }^{14} \mathrm{C}\right]$ glucose radioactivity (half-lives 9 and $13 \mathrm{~min}$, respectively) as compared to IGFBP-3 alone (half-life $\sim 43 \mathrm{~min}$ ). Similar results were obtained after correcting for the serum glucose level (specific $\left[{ }^{14} \mathrm{C}\right]$ glucose radioactivity, Fig. $1 C$ ). In hypox rats, the disappearance rate of the specific $\left[{ }^{14} \mathrm{C}\right]$ glucose radioactivity after the IGF I/IGFBP-3 bolus became identical to that after the IGF I bolus (Fig. $1 C$ ).

Effect of IGF I, IGFBP-3, and IGF I/IGFBP-3 complex on glucose incorporation into diaphragm glycogen and fat pad total lipids. In normal rats, only the IGF I bolus significantly stimulated glucose incorporation into diaphragm glycogen, whereas IGFBP-3 alone and the IGF I/IGFBP-3 complex had no stimulatory effect (Fig. $2 A$ ). In contrast, the IGF I/IGFBP3 complex like IGF I enhanced glycogen synthesis in diaphragm of hypox rats to a similar extent during the first $120 \mathrm{~min}$ (Fig. $2 A$ ). Similar to glycogen synthesis, incorporation of $U-\left[{ }^{14} \mathrm{C}\right]-$ glucose into fat pad total lipids of normal rats was only stimulated by the IGF I bolus (Fig. $2 B$ ). No stimulation of lipid synthesis was observed in hypox rats with any of the three compounds (Fig. $2 B$ ). The lack of an IGF I effect on lipid synthesis in fat pads of hypox rats confirms earlier findings (10) and is compatible with the observation that adipose tissue and isolated fat cells of hypox rats where IGF I acts via the insulin receptor are "refractory" to insulin stimulation of lipid synthesis $(21,22)$.

Serum half-lives of IGF I and IGFBP-3 after injection of IGF I, IGFBP-3, or IGF I/IGFBP-3 complex. The results obtained with the IGFBP-3-RIA (Fig. $3 B$ ) agree reasonably well with those obtained by Western ligand blotting (Fig. $3 C$ ). As shown earlier (10), the serum half-life of i.v. injected IGF I is considerably longer in normal than in hypox rats (Fig. $3 \mathrm{~A}$ ). In normal rats, IGF I disappears more rapidly after IGF I than after the IGF I/IGFBP-3 complex during the first $5 \mathrm{~min}$ of the experiment. Later, the disappearance rates become similar, although they are somewhat slower in the case of the complex ( $\sim 7$ and 9 min between 5 and 20 min after injection, 100 and $120 \mathrm{~min}$ following $20 \mathrm{~min}$ after injection; Fig. $3 \mathrm{~A}$ ). Furthermore, IGF I levels are significantly higher at all time points after injection of the complex. (Fig. $3 \mathrm{~A}$ ). In hypox rats, IGF I levels 5 and $20 \mathrm{~min}$ after the IGF I and the IGF I/IGFBP-3 bolus are the same. After $20 \mathrm{~min}$, IGF I disappears with a halflife of 16 and $24 \mathrm{~min}$, respectively, after the IGF I/IGFBP-3 and the IGF I bolus (Fig. $3 \mathrm{~A}$ ). In contrast to normal rats, IGF I levels at 60 and $120 \mathrm{~min}$ are lower with the IGF I/IGFBP-3 than with the IGF I bolus.

The disappearance kinetics of IGFBP-3 after iv administration of the IGF I/IGFBP-3 complex closely resemble those of IGF I. This is true in normal as well as in hypox rats (Fig. 3). 20 min after injection of the complex, IGFBP-3 disappears with a half-life of 80-100 $\mathrm{min}$ in normal and 14-15 $\mathrm{min}$ in hypox rats as calculated from the RIA and the Western ligand blot data, respectively (Fig. $3 B$ and $C$ ). Surprisingly, $5 \mathrm{~min}$ after injection of IGFBP-3 alone, the serum IGFBP-3 level has dropped to $5-10 \%$ of the level after injection of the complex in both normal and hypox rats. After $20 \mathrm{~min}$, however, the disappearance rates of IGFBP-3 become similar whether IGFBP-3 alone or the complex has been injected, but they are faster in hypox $\left(t_{1 / 2}=40-50 \mathrm{~min}\right)$ than in normal animals $\left(t_{1}\right.$ ${ }_{2}=100-110 \mathrm{~min}$ ).

The distribution of IGFBP-3 and IGF I after administration of the complex differs considerably between normal and hypox rats (Fig. $4 A$ and $B$ ). In normal rats, most of the IGF I and IGFBP-3 is found in the range of the $150-\mathrm{kD}$ IGFBP complex after 20 and $60 \mathrm{~min}$, whereas both compounds appear mainly in the range of the $40-\mathrm{kD}$ BP complex in hypox rats after 5 and $20 \mathrm{~min}$ and are barely detectable after $60 \mathrm{~min}$. A minor portion of IGF I and IGFBP-3 eluting in the $150-\mathrm{kD}$ region of hypox serum which lacks the $150-\mathrm{kD}$ ternary complex (4) disappears with the same half-life as in the $40 \mathrm{kDa}$ complex (fig. 4B), suggesting that the two compounds are not complexed with ALS. Their appearance within the $150-\mathrm{kD}$ range may result from transient nonspecific association with serum proteins.

\section{Discussion}

The aim of this study was to answer the question whether or not iv injected 1:1 molar IGF I/IGFBP-3 complex, like IGF I itself, can elicit acute insulin-like effects on glucose homeostasis in normal or hypox rats. To this end, the effects of the complex on serum glucose levels and glucose incorporation into diaphragm glycogen and epididymal fat pad total lipids were compared with the effects of each of the single components. These were administered at the same dose in which they were present in the complex. A second question of interest addressed the elimination kinetics of the IGF I/IGFBP-3 complex as compared to those of IGF I or IGFBP-3 injected alone.

Since we used nonglycosylated instead of glycosylated IGFBP-3, the "physiological" form occurring in serum, the first question which arises is whether or not the nonglycosylated IGFBP-3 is equivalent to the glycosylated form. As shown by Sommer et al. (17), no substantial difference in the properties of glycosylated and nonglycosylated IGFBP-3 have been observed except for the association kinetics of the sc injected binary IGF I/nonglycosylated IGFBP-3 complex with ALS which was retarded as compared to that of the binary IGF I/glycosylated IGFBP-3 complex. Nevertheless, these authors showed that association does occur and, as discussed below, this was also found in the present study with the iv administered IGF I/ nonglycosylated IGFBP-3 complex. Therefore, interpretation of our results should not be fundamentally affected by the use of nonglycosylated instead of glycosylated IGFBP-3.

Our study shows a conspicuous difference between the effects of the i.v. injected IGF I/IGFBP-3 complex in normal and those in hypox rats: blood sugar levels did not significantly change in normal animals during the first $2 \mathrm{~h}$ after injection of the complex, nor were glycogen synthesis in diaphragm or lipid synthesis in adipose tissue stimulated as observed after the IGF I bolus. In contrast, the blood sugar level dropped significantly, although less pronounced than with IGF I, in hypox rats, and glycogen synthesis was enhanced during 2 hours to the same extent as with IGF I. These results suggest that the IGF I of the complex must have gained access to insulin and/or type I 


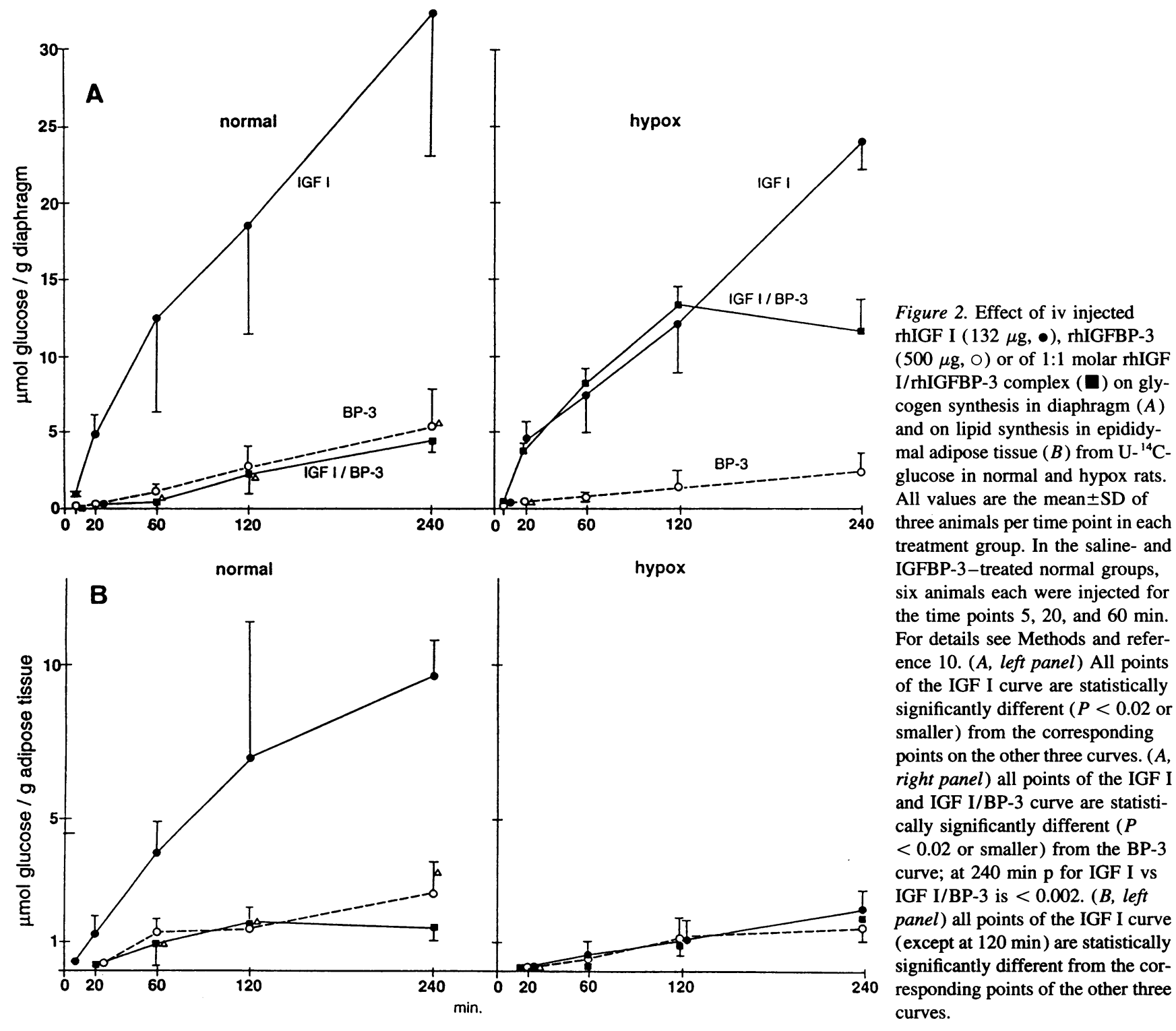

IGF receptors in skeletal muscle of hypox animals and interacted with these receptors to stimulate glucose entry into the tissue. Obviously, this does not occur to a significant extent in normal animals.

The above results are reflected by the disappearance kinetics of the co-injected $\mathrm{U}-\left[{ }^{14} \mathrm{C}\right]$ glucose: in agreement with the effect of the IGF I/IGFBP-3 complex on glucose homeostasis in hypox rats the disappearance rates of ${ }^{14} \mathrm{C}$-radioactivity and of specific glucose radioactivity are enhanced and similar to those obtained with the IGF I bolus, whereas in normal rats, in the absence of acute insulin-like effects, they are similar to those in the saline- and IGFBP-3-treated groups.

The absence of a stimulatory effect not only of the IGF I/ IGFBP-3 complex but also of IGF I itself on lipid synthesis in adipose tissue of hypox animals, may at first sight, appear contradictory to stimulation of glycogen synthesis in diaphragm, but is explained as follows: adipose tissue and isolated fat cells from hypox rats are unresponsive to insulin stimulation of lipid synthesis from glucose $(21,22)$. Since IGF I acts on rat adipose tissue via the insulin receptor $(23,24)$ it is unable to stimulate this parameter in hypox animals (Fig. $2 A$ and reference 10 ).

In a previous study, Sommer et al. (18) reported that IGFBP- 3 injected sc together with IGF I in hypox rats reduced hypoglycemia as compared to sc injected IGF I alone. Although these results are not readily comparable with ours because of the different route of administration of the compounds and because blood sugar levels were measured only $2 \mathrm{~h}$ after injection, they do not essentially disagree with our findings: indeed, the hypoglycemic effect of iv injected IGF I/IGFBP-3 complex in hypox rats was less pronounced and less sustained than that of the corresponding dose of IGF I.

Another information obtained by our study concerns the effect of i.v. injected IGFBP-3: neither in normal nor in hypox animals did it cause significant changes of the blood sugar level nor stimulation of glycogen synthesis in skeletal muscle. The former finding is in contrast to the report of Lewitt et al. (25) that an iv bolus of $100 \mu \mathrm{g}$ of IGFBP-1 caused an immediate $10 \%$ rise of the blood sugar level in fasting rats. Whether this 

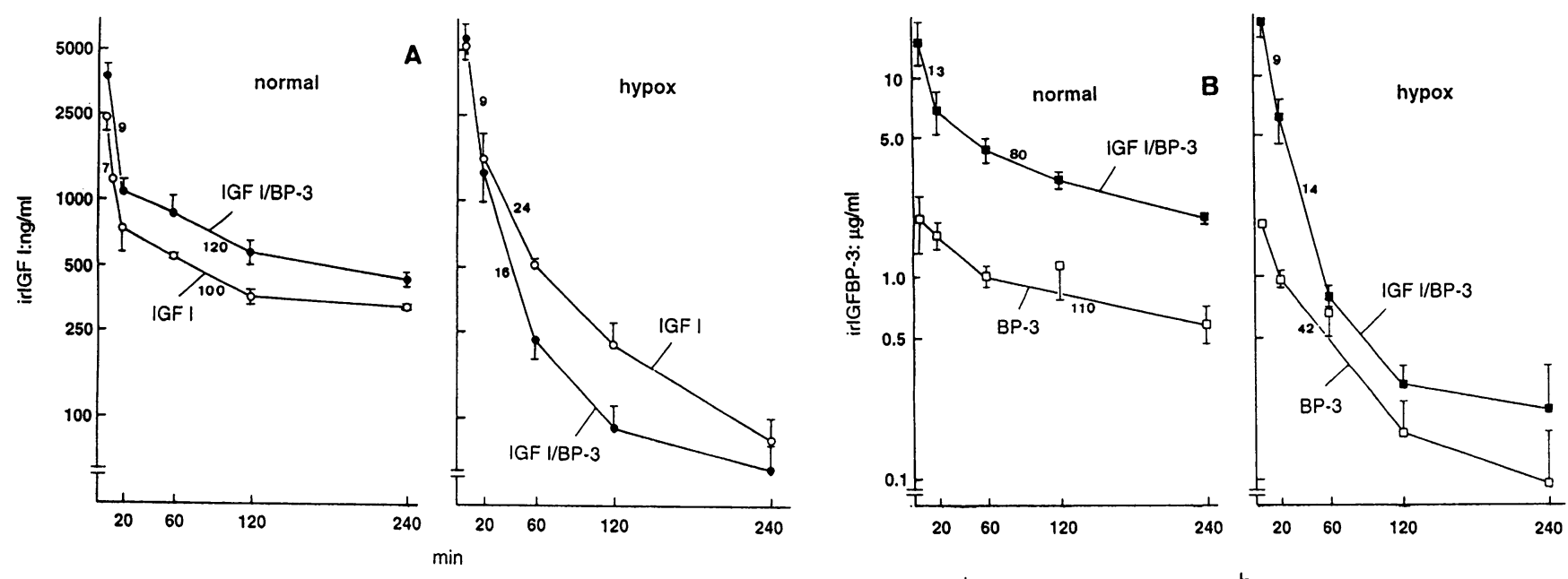

Figure 3. Serum disappearance rates of rhIGF I $(A)$ after iv injection of rhIGF $(O)$ or of 1:1 molar rhIGF I/rhIGFBP-3 complex $(\bullet)$ and serum disappearance rates of IGFBP-3 after i.v. injection of rhIGFBP-3 (口) or 1:1 molar rhIGF I/ rhIGFBP-3 complex ( $\square$ ) in normal and hypox rats. Human IGF I and IGFBP-3 were determined by RIA as described in Methods and in references 4 and 19. IGFBP-3 was also determined by Western ligand blotting $(C)$ (see Methods). All values represent the mean \pm SD for three animals per time point in each treatment group, except in the IGFBP-3-treated normal group where six animals each were injected for the time points 5,20 , and $60 \mathrm{~min}$. The numbers in the figures indicate the half-lives during the first $20 \mathrm{~min}$ and after $20 \mathrm{~min}$, respectively, starting at 5 min after injection.

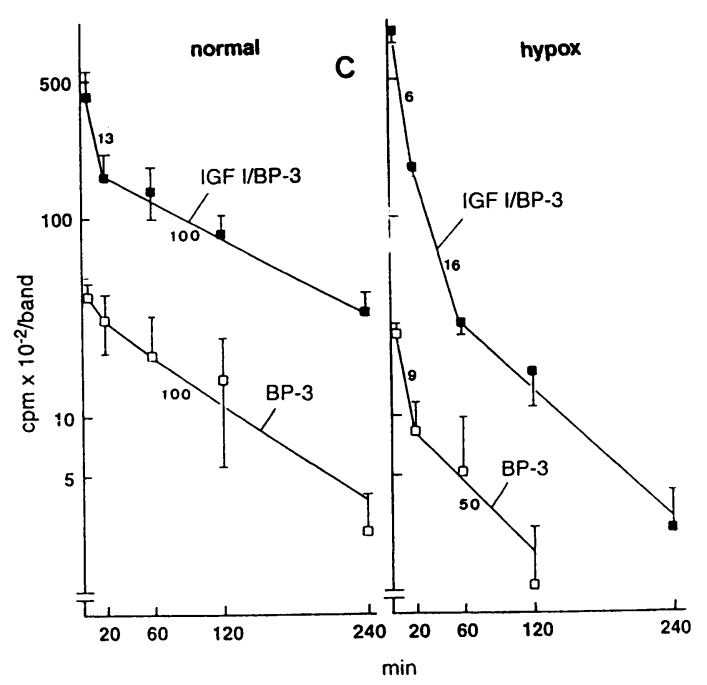

discrepancy is due to different inherent properties of the two BPs or to differences in the experimental design remains to be clarified.

One might argue that the acute insulin-like effects exerted by the IGF I/IGFBP-3 complex in hypox rats are due to the presence of free IGF I. However, as determined by neutral sizing chromatography (17) and immunometric assay (18) free IGF I was at the limit of detection and was estimated $<5 \%$ of the total IGF I present in the complex, i.e. $<6 \mu \mathrm{g} /$ injection. Although we have not tested this dose in hypox animals it appears unlikely that it would enhance glycogen synthesis in diaphragm and the disappearance of specific glucose radioactivity to the same extent as the $>20$-fold higher dose of the IGF I bolus. On the other hand, in vitro studies have shown that IGF I in the presence of an equimolar amount of IGFBP-3 can stimulate glycogen synthesis in cultured human osteoblastic cells to a similar extent as IGF I alone (only excess IGFBP-3 inhibited IGF I action) (26).

Nevertheless, the following question remains to be answered: why does the i.v. injected IGF I/IGFBP-3 complex elicit acute insulin-like actions in hypox, but not in normal animals? An explanation for this difference is provided by the different elimination kinetics of the complex in normal and hypox animals (Figs. 3 and 4 ) which in turn are due to differences in the ability of injected binary IGF I/IGFBP-3 complex to form the $150-\mathrm{kD}$ ternary IGFBP complex in serum. As shown in Fig. 3, the half-life of IGF I and IGFBP-3 $20 \mathrm{~min}$ after injection of the complex is 6-8-fold shorter in hypox than in normal animals. This difference which is also found for i.v.injected IGF I (Fig. 3 and reference 10) is explained by the lack in hypox serum of the $150-\mathrm{kD}$ heterotrimer (4) due to deficiency of the ALS (27). In normal animals where ALS is present in a free form in molar excess of the complex (28), the injected IGF I/IGFBP-3 complex should be able to form the $150-\mathrm{kD}$ heterotrimer. Thereby, passage of IGF through capillaries is prevented (13), IGF is retained in the circulation and, as postulated earlier (1) rendered inactive with respect to regulation of glucose homeostasis. This explanation is in line with our finding that in normal serum most of the IGF I and IGFBP3 after injection of the IGF I/IGFBP-3 bolus elutes in the range of the 150-kD IGFBP complex on neutral Sephadex G-200 gel permeation chromatography (Fig. 4). In hypox serum, however, most of the IGF I and IGFBP-3 is found in the range of the 40-kD IGFBP complex (Fig. 4) because ALS is lacking and formation of the $150-\mathrm{kD}$ heterotrimer cannot occur. As a consequence, the injected IGF I/IGFBP-3 appears to be rapidly cleared from the circulation.

The finding that the disappearance rates of IGF I and IGFBP-3 after complex injection in hypox rats are identical ( 9 min after $5 \mathrm{~min}$ of injection, and 14-16 min after $20 \mathrm{~min}$ of injection) suggests that the two compounds may be cleared together as IGF I/IGFBP-3 complex. This notion would be 

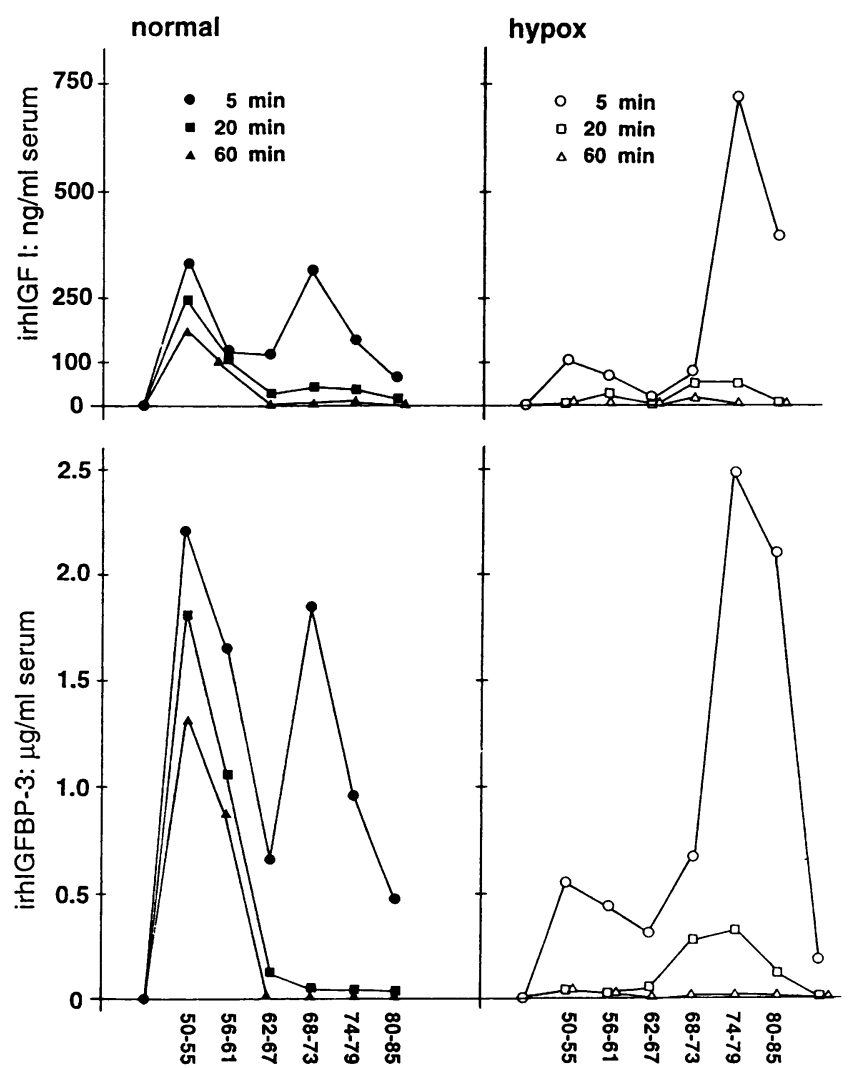

Figure 4. Disappearance of rhIGF I and rhIGFBP-3 in serum fractions obtained by neutral Sephadex G-200 gel filtration of sera from normal (closed symbols) and hypox rats (open symbols) 5, 20, and $60 \mathrm{~min}$ after i.v. injection of 1:1 molar rhIGF I/rhIGFBP-3 complex (132/500 $\mu \mathrm{g} / \mathrm{rat}) .0 .6 \mathrm{ml}$ of pooled serum from three rats per time point was gelfiltered on a Sephadex G-200 column at neutral pH (see Methods). Eluted fractions $(2.4 \mathrm{ml}$ ) were pooled as indicated on the abscissa and processed as described in Methods. Human IGF I was determined by RIA after processing over SepPak $\mathrm{C}_{18}$-cartridges (4). Human IGFBP3 was measured by RIA as described in Methods. Pooled fractions 5055 and 56-61 correspond to the $150-\mathrm{kD}$ and pools $62-67,68-73,74-$ 79 , and $80-85$ to the $40-\mathrm{kD}$ IGFBP complexes. The elution range of these complexes was determined by gel filtration on the same column of normal and hypox rat serum which had been preequilibrated with ${ }^{125}$ I-rhIGF II as described earlier (reference 4).

consistent with the observation of.Bar et al. (29) that endothelial cell IGFBP cross-linked to ${ }^{125}$ I-IGF I crosses capillary boundaries during perfusion of the isolated rat heart. In this model, coupling of IGF I to the BP also altered the physicochemical properties of the BP such that the complex was preferentially localized to muscle instead of connective tissue, identical to the localization of IGF I when the hearts were perfused with IGF I in the absence of BP. The authors reasoned that the IGF I component may direct the complex to the IGF receptors of cardiac myocytes. Such a mechanism, if operative also in skeletal muscle with the IGF I/IGFBP-3 complex, would well fit our finding in hypox rats showing stimulation by the complex of glycogen synthesis in diaphragm. In our study, the IGF I of the complex disappears even more rapidly $20 \mathrm{~min}$ after injection than IGF I injected alone (Fig. 3). One could, therefore, speculate that in the absence of ALS, IGFBP-3 facilitates the transcapillary passage of IGF I. On the other hand, IGF I injected alone disappears more rapidly than complexed IGF I during the first $5 \mathrm{~min}$ after injection in normal rats, indicating that in the presence of excess ALS, IGFBP-3 retards the initial disappearance rate of IGF I due to rapid formation of the $150-\mathrm{kD}$ heterotrimer.

One of the surprising findings of the study concerns the disappearance of iv injected IGFBP-3 in both normal and hypox animals. 5 min after injection, the serum IGFBP-3 levels had dropped to $5-10 \%$ of the level following injection of the IGF I/IGFBP-3 complex. This finding is in contrast to the results reported by Lewitt et al. (30) who injected an iv bolus (130 $\mu \mathrm{g} / \mathrm{kg}$ ) of human IGFBP-3, purified from Cohn fraction IV of human plasma, into normal rats and found $>50 \%$ of it in the $150-\mathrm{kD}$ complex already 2 min after injection. Because IGFBP3 must bind IGF before it can associate with ALS (3), these authors concluded that a large pool of IGFs must be readily available to the circulation in order to explain this finding. They estimated that $\sim 700 \mathrm{ng} / \mathrm{ml}$ of IGF I would be required for complexing $50 \%$ of the injected IGFBP-3 within the $150-\mathrm{kD}$ ternary complex (30). However, total IGF I levels in the IGFBP-3-injected animals were not reported. We have measured IGF I in the sera of our saline- and IGFBP-3-injected normal rats but have been unable to find significant differences during the 4-h period of our experiment. The discrepancy between Lewitt's and our findings might be due to the different IGFBP-3 preparations used, i.e., the glycosylated form in Lewitt's and the nonglycosylated form in our experiments. For example, association of the nonglycosylated form with IGF I and acid-labile subunit may not occur as rapidly as with the glycosylated form. Indeed, Sommer et al. (17) reported that association of sc injected IGF I/nonglycosylated IGFBP-3 complex with ALS was delayed as compared to that of the IGF I/glycosylated IGFBP-3 complex. Nevertheless, if a large pool of IGF I were available to the circulation, as postulated by Lewitt et al. (30), one would expect significant amounts of this IGF I to be bound to the relatively large quantity $(\sim 3 \mathrm{mg} / \mathrm{kg})$ of injected nonglycosylated IGFBP-3. This should be measurable even though formation of the ternary complex was retarded, since the affinities of the glycosylated and nonglycosylated forms for IGF I are the same (17).

To find an explanation for the rapid disappearance of rhIGFBP-3 during the first $5 \mathrm{~min}$ of injection, we have tested by immunoblotting whether injected free rhIGFBP-3 is rapidly degraded in the circulation. At no time point have we found significant amounts of degradation products of rhIGFBP-3 either in normal or hypox animals (not shown). Possibly, most of the injected rhIGFBP-3 leaves the circulation very rapidly or is removed from the circulation by binding to the vascular endothelium.

Finally, our studies may provide some clues to the pathogenesis of extrapancreatic tumor hypoglycemia (EPTH) in man. In this paraneoplastic syndrome, an incompletely processed form of IGF II (big IGF II) produced by the tumor cannot adequately associate to form the $150-\mathrm{kD}$ ternary complex and circulates mainly as a small molecular weight binary IGF II/ IGFBP complex $(5,15,16)$. One of the prerequisites for the development of hypoglycemia in EPTH is that complexed big IGF II can exert acute insulin-like effects. Indeed, this is true for a 1:1 molar IGF I/IGFBP-3 complex in the absence of the $150-\mathrm{kD}$ ternary complex as shown here. In analogy to hypox rats injected with the IGF I/IGFBP-3 complex, patients with EPTH display low serum insulin levels and suppressed GH secretion besides impaired formation of the $150-\mathrm{kD}$ ternary 
complex and a circulating "free" 40-kD IGFBP pool loaded with IGF (in this case big IGF II) $(16,31,32)$. Like in hypox animals, IGF II associated with the latter BP pool may rapidly leave the circulation (8) and reach insulin target tissues. However, in contrast to hypox rats injected with the IGF I/IGFBP3 complex, the situation in patients with EPTH corresponds to a constant iv infusion of an IGF II/IGFBP complex which permanently carries big IGF II produced by the tumor into the interstitial fluid and thus floods insulin target tissues with this insulin-like substance which then exerts sustained insulin-like effects and causes severe fasting hypoglycemia.

\section{Acknowledgments}

We thank Ms. I. Buclin and M. Salman for devoted secretarial help. This work was supported by grant 32-31281.91 of the Swiss National Science Foundation.

\section{References}

1. Zapf, J., C. Schmid, and E. R. Froesch. 1984. Biological and immunological properties of insulin-like growth factors (IGF) I and II. In Clinics in Endocrinology and Metabolism. Tissue growth factors. W. H. Daughaday, editor. vol. 13/ $1,3-30$.

2. Moses, A. C., S. P. Nissley, J. Passamani, R. M. White, and M. M. Rechler 1984. Further characterization of growth hormone-dependent somatomedin-binding proteins in rat serum and demonstration of somatomedin-binding proteins produced by rat liver cells in culture. Endocrinology. 104:536-546.

3. Baxter, R. C., and J. L. Martin. 1989. Structure of the $M_{\mathrm{r}} 140,000$ growth hormone-dependent insulin-like growth factor binding protein complex: determination by reconstitution and affinity labeling. Proc. Natl. Acad. Sci. USA. $86: 6889-6902$.

4. Zapf, J., C. Hauri, M. Waldvogel, E. Futo, H. Häsler, K. Binz, H. P. Guler, C. Schmid, and E. R. Froesch. 1989. Recombinant human insulin-like growth factor I induces its own specific carrier protein in hypophysectomized and diabetic rats. Proc. Natl. Acad. Sci. USA. 86:3813-3817.

5. Zapf, J., Ch. Schmid, H. P. Guler, M. Waldvogel, Ch. Hauri, E. Futo, P. Hossenlopp, M. Binoux, and E. R. Froesch. 1990. Regulation of binding proteins for insulin-like growth factors (IGF) in man: increased expression of IGF binding protein-2 during IGF I treatment of healthy adults and in patients with extrapancreatic tumor hypoglycemia. J. Clin. Invest. 86:952-961.

6. Zapf, J., M. Kiefer, J. Merryweather, F. Masiarz, D. Bauer, W. Born, J. A. Fischer, and E. R. Froesch, 1990. Isolation from adult human serum of four insulin-like growth factor (IGF) binding proteins and molecular cloning of one of them that is increased by IGF I administration and in extrapancreatic tumor hypoglycemia. J. Biol. Chem. 265:14892-14898.

7. Keifer, M. C., F. R. Masiarz, D. M. Bauer, and J. Zapf. 1991. Identification and molecular cloning of two new $30 \mathrm{kD}$ insulin-like growth factor binding proteins (IGFBP) isolated from adult human serum. J. Biol. Chem. 266:90439049.

8. Guler, H. P., J. Zapf, Ch. Schmid, and E. R. Froesch. 1989. Insulin-like growth factors I and II in healthy man: estimations of half-lives and production rates. Acta Endocrinol. 121:753-758.

9. Guler, H. P., J. Zapf, E. Scheiwiller, and E. R. Froesch. 1988. Recombinan human insulin-like growth factor I stimulates growth and has specific effects on organ size in hypophysectomized rats. Proc. Nat. Acad. Sci. USA. 85:4889-4893.

10. Zapf, J., Ch. Hauri, M. Waldvogel, and E. R. Froesch. 1986. Acute metabolic effects and half-lives of intravenously administered insulin-like growth factors I and II in normal and hypophysectomized rats. J. Clin. Invest. 77:17681775 .

11. Guler, H. P., J. Zapf, and E. R. Froesch. 1987. Short-term metabolic effects of recombinant human insulin-like growth factor $I$ in healthy adults. $N$. Engl. J. Med. 317:137-140.

12. Jacob, R., E. Barrett, G. Plewe, D. Fagin, and R. S. Sherwin. 1989. Acute effects of insulin-like growth factor I on glucose and amino acid metabolism in the awake fasted rat. J. Clin. Invest. 83:1717-1723.

13. Binoux, M., and P. Hossenlopp. 1988. Insulin-like growth factor (IGF) and IGF-binding proteins: comparison of human serum and lymph. J. Clin. Endocrinol. Metab. 67:509-514.

14. Cohen, K. L., and S. P. Nissley. 1975. Comparison of somatomedin activity in rat serum and lymph. Acta Endocrinol. 97:654-658.

15. Daughaday, W. H., and M. Kapadia. 1989. Significance of abnormal serum binding of insulin-like growth factor II in the development of hypoglycemia in patients with non-islet-cell tumors. Proc. Natl. Acad. Sci. USA. 86:6778-6782.

16. Zapf, J., E. Futo, M. Peter, and E. R. Froesch. 1992. Can "big"' insulinlike growth factor II in serum of tumor patients account for the development of extrapancreatic tumor hypoglycemia? J. Clin. Invest. 90:2574-2584.

17. Sommer, A., S. K. Spratt, G. P. Tatsumo, T. Tressel, R. Lee, and C. A. Maack. 1993. Properties of glycosylated and non-glycosylated human recombinant IGF binding protein-3 (IGFBP-3). Growth Regulation. 3:46-49.

18. Sommer, A., C. A. Maack, S. K. Spratt, D. Mascarenhas, T. J. Tressel, E. T. Rhodes, R. Lee, M. Roumas, G. P. Tatsuno, J. A. Flynn, N. Gerber, J. Taylor, H. Cudry, L. Nanney, T. K. Hunt, and E. M. Spencer. 1991. Molecular genetics and actions of recombinant insulin-like growth factor binding protein-3. In Modern Concepts of Insulin-Like Growth Factors. E. M. Spencer, editor. Elsevier, New York.

19. Zapf, J., H. Walter, and E. R. Froesch. 1981. Radioimmunological determination of insulin-like growth factors (IGF) I and II in normal subjects and in patients with growth disorders and extrapancreatic tumor hypoglycemia. J. Clin. Invest. 68:1321-1330.

20. Hossenlopp, P., D. Seurin, B. Segovia-Quinson, S. Hardouin, and M. Binoux. 1986. Analysis of serum insulin-like growth factor binding proteins using Western blotting: use of the method for titration of the binding proteins and competitive binding studies. Anal. Biochem. 154:138-143.

21. Schoenle, E., J. Zapf, and E. R. Froesch. 1979. Effects of insulin on glucose metabolism and glucose transport in fat cells of hormone-treated hypophysectomized rats: Evidence that growth hormone restricts glucose transport. Endocrinology. 105:1237-1242.

22. Zapf, J., M. Waldvogel, E. Schoenle, and E. R. Froesch. 1981. Effect of insulin on glucose transport and metabolism in adipose tissue and skeletal muscle of hypophysectomized rats. FEBS (Fed. Eur. Bichem. Soc.) Lett. 135:199-202.

23. King, G. L., R. Kahn, M. M. Rechler, and S. P. Nissley. 1980. Direc demonstration of separate receptors for growth and metabolic activities of insulin and multiplication stimulating activity (an insulin-like growth factor) using antibodies to the insulin receptor. J. Clin. Invest. 66:130-140.

24. Zapf, J., E. Schoenle, M. Waldvogel, I. Sand, and E. R. Froesch. 1981 Effect of trypsin treatment of rat adipocytes on biological effects and binding of insulin-like growth factor. Further evidence for the action of insulin-like growth factor through the insulin receptor. Eur. J. Biochem. 113:605-609.

25. Lewitt, M. S., G. S. Denyer, G. J. Cooney, and R. C. Baxter. 1991. Insulinlike growth factor-binding protein-1 modulates blood glucose levels. Endocrinology. 129:2254-2256.

26. Schmid, Ch., J. Rutishauser, I. Schläpfer, E. R. Froesch, and J. Zapf. 1991 Intact, but not truncated insulin-like growth factor binding protein-3 (IGFBP-3 blocks IGF-I-induced stimulation of osteoblasts: control of IGF-signalling to bone cells by IGFBP-3-specific proteolysis. Biochem. Biophys. Res. Commun. 179:579_ 585.

27. Scott, C. D., and R. C. Baxter. 1991. Synthesis of the acid-labile subunit of the growth hormone-dependent insulin-like growth factor binding protein complex by rat hepatocytes in culture. Biochem. J. 275:441-446.

28. Baxter, R. C. 1988. Characterization of the acid-labile subunit of the growth hormone-dependent insulin-like growth factor binding protein complex. J. Clin. Endocrinol. Metab. 67:265-272.

29. Bar, R. S., M. Boes, B. L. Dake, A. Sandra, M. Bayne, M. Cascieri, and B. A. Booth. 1990. Time localization of perfused endothelial cell IGF binding protein is markedly altered by association with IGF I. Endocrinology. 127:32433245 .

30. Lewitt, M. S., H. Saunders, and R. C. Baxter. 1993. Bioavailability of insulin-like growth factors (IGFs) in rats determined by the molecular distribution of human IGF-binding protein-3. Endocrinology. 133:1797-1802.

31. Baxter, R. C., and W. H. Daughaday. 1991. Impaired formation of the ternary insulin-like growth factor-binding protein complex in patients with hypoglycemia due to nonislet cell tumors. J. Clin. Endocrinol. Metab. 73:696-702.

32. Daughaday, W. H., B. Trivedi, and R. C. Baxter. 1993. Serum " big insulinlike growth factor II' from patients with tumor hypoglycemia lacks normal Edomain O-linked glycosylation, a possible determinant of normal propeptide processing. Proc. Natl. Acad. Sci. USA. 90:5823-5827 